\title{
Pengaruh Media Sosial terhadap Efikasi Keputusan Perjalanan Generasi Z dalam Memilih Destinasi Wisata di Jabodetabek
}

\author{
Sisilia Alvionita*1, Eveline Gaby Sutanto², Natasha Dyah Ayuningtyas ${ }^{3}$, Nyoman \\ Krisna Wati ${ }^{4}$, Made Handijaya Dewantara ${ }^{5}$ \\ Hospitality Business Universitas Prasetiya Mulya, Indonesia1,2,3,4,5 \\ Email: made.handijaya@pmbs.ac.id
}

\begin{abstract}
This study aims to determine the differences in social electronic word-of-mouth and travel motivation for Generation $\mathrm{Z}$ who are living in the Jabodetabek area. This research was conducted because it had never been done by previous researchers. The data collection used is by using a survey through Google Forms and literature studies from various journals. This study uses a quantitative approach by analyzing data through the IBM SPSS system. The results showed that there was a positive and significant relationship that the efficacy of generation $\mathrm{Z}$ travel decisions in choosing tourist destinations in the Jabodetabek area was influenced by the existence of the social electronic word of mouth and travel motivation. However, the differences in social electronic word-of-mouth and travel motivation among Generation $\mathrm{Z}$ who live in the Jabodetabek area are not homogeneous. Therefore, the calculation of the efficacy of their travel decisions also cannot be equated. The goals and motivations for the journey of Generation $\mathrm{Z}$ who live in Jakarta are not necessarily the same as Generation $\mathrm{Z}$ who live in other regions.
\end{abstract}

Keywords: social electronic word of mouth, travel motivation, travel decision efficacy, generation $\mathrm{Z}$.

\begin{abstract}
Abstrak
Penelitian ini bertujuan untuk mengetahui perbedaan social electronic word-of-mouth dan motivasi perjalanan Generasi Z yang berdomisili di wilayah Jabodetabek. Pengumpulan data yang digunakan adalah dengan menggunakan survei melalui Google Forms dan studi literatur dari berbagai jurnal. Penelitian ini menggunakan pendekatan kuantitatif dengan menganalisa data melalui sistem IBM SPSS. Hasil penelitian menunjukkan adanya hubungan yang positif dan signifikan bahwa efikasi keputusan perjalanan generasi $\mathrm{Z}$ dalam memilih destinasi wisata di wilayah Jabodetabek dipengaruhi oleh adanya social electronic word of mouth dan travel motivation. Namun, perbedaan dalam social electronic word-of-mouth dan motivasi perjalanan di antara Generasi Z yang berdomisili di wilayah Jabodetabek tidak homogen. Oleh karena itu, perhitungan efikasi keputusan perjalanan mereka juga tidak dapat disamakan. Tujuan dan motivasi perjalanan Generasi Z yang berdomisili di Jakarta belum tentu sama dengan Generasi Z yang berdomisili di wilayah lainnya.
\end{abstract}

Kata Kunci: social electronic word of mouth; travel motivation; efikasi keputusan perjalanan; generasi Z.

\section{A. PENDAHULUAN}

Menurut Syukur Kholil (2011), dengan kemajuan teknologi di Indonesia saat ini banyak memberikan dampak yang cukup besar untuk kehidupan masyarakat yang modern. Dengan perkembangan teknologi yang semakin meluas, membuat orang-orang semakin mudah dalam mempromosikan destinasi wisata yang baru. Adanya media sosial sangat membawa dampak yang besar kepada industri pariwisata Indonesia. Media sosial sebagai salah satu media yang banyak dijadikan sebagai tempat untuk mempromosikan barang/jasa, serta digunakan juga untuk mempromosikan tempat wisata. Hal itu membuat para traveler dengan sangat mudah mengakses lokasi wisata, mengetahui fasilitas yang disediakan, serta experience yang akan dirasakan jika berkunjung ke destinasi tersebut.

* Corresponding author 
Di Indonesia sendiri, pengguna media sosial aktif mencapai 150 juta orang dan sebesar 97\% pengguna media sosial adalah Generasi Z dan Milenial (Google Trend Indonesia, 2020). Selain itu, dikutip dari laman resmi We Are Social, per Januari 2020 di seluruh dunia terdapat 3,8 miliar pengguna media sosial. Angka penggunanya cukup meningkat hingga $9 \%$ atau 321 juta pengguna baru sejak tahun lalu (Okezone, 2020).

Generasi Z adalah orang yang lahir pada tahun 1993 sampai dengan tahun 2005 (Taylor \& Keeter, 2010). Sebagian besar Generasi $Z$ telah fasih dalam menggunakan media sosial. Hal ini didukung dengan data We Are Social Hootsuite pada bulan Januari 2020 di Indonesia, di mana Generasi Z merupakan pengguna media sosial yang menduduki peringkat tiga besar diantara usia lainnya. Oleh karena itu, Generasi $\mathrm{Z}$ dikenal sebagai pecandu yang naif, yang selalu ingin terhubung dengan digital (Koulopoulos dan Keldsen, 2014). Hal ini disebabkan karena mereka adalah generasi pertama yang memiliki akses ke teknologi komunikasi digital dengan skala besar, baik dalam bentuk ponsel, Wi-Fi, serta permainan komputer berinteraksi (Bassiouni dan Hackley, 2014). Mereka pun menganggap ponsel pintar adalah bagian penting dalam kehidupan mereka (Ozkan dan Solmaz, 2014). Selain itu, banyak Generasi Z yang tidak terlalu mendapatkan perhatian, banyak generasi ini yang tumbuh dengan orang tua tunggal, sehingga mereka hidup dengan mandiri (Koulopoulos dan Keldsen, 2014). Dengan banyaknya penggunaan media sosial di Indonesia, membuat orang-orang mudah mengetahui segala informasi seputar tempat baru, budaya baru, serta aktivitas yang dilakukan masyarakat lokal. Sehingga untuk di Indonesia khususnya, sangat berpeluang untuk menjadikan media sosial sebagai tempat untuk melakukan pemasaran destinasi dan budaya Indonesia di ranah nasional dan global.

Ada survei yang menyatakan bahwa sebanyak $87 \%$ wisatawan menggunakan internet dan media sosial untuk merencanakan perjalanan wisata. Selain itu, $40 \%$ wisatawan mengunjungi situs jejaring sosial dalam memilih destinasi wisata yang berdasarkan rekomendasi dari pengguna media sosial lainnya (Fitriani, 2017). Dalam hal ini, dengan didukung data Badan Pusat Statistik mengenai banyaknya wisatawan lokal maupun mancanegara yang berkunjung ke Indonesia dan juga Jakarta (Data Badan Pusat Statistik, 2015), maka penulis ingin mengetahui bagaimana hubungan media sosial bagi Generasi Z dalam memilih Indonesia dan wilayah Jabodetabek sebagai destinasi untuk berwisata.

Hingga saat ini, sudah banyak peneliti atau riset yang telah melakukan penelitian mengenai niat, minat, motivasi, dan perilaku Generasi X, Y, dan Z terhadap bidang pariwisata di Indonesia, namun hingga kini belum ada yang membahas mengenai pengaruh media sosial terhadap efikasi keputusan perjalanan Generasi Z mengenai kepercayaan individu akan menentukan destinasi wisata, khususnya di Indonesia. Pada dasarnya, internet telah mengubah cara manusia dalam mencari data (Abid, 2017). Dan berbagai informasi mengenai destinasi wisata di Indonesia telah ada di berbagai situs maupun aplikasi, sehingga akan sangat mudah dalam mencari berbagai informasi mengenai pariwisata Indonesia. Informasi yang tersedia pun sudah sangat jelas, yang dapat dilihat melalui berbagai situs, seperti indonesia.travel dan jakarta-tourism.go.id. Warga Negara Indonesia atau warga negara asing pun dapat mengakses informasiinformasi tersebut dengan mudah. Hal ini disebabkan karena media sosial dioptimalkan sebagai wadah promosi interaktif dalam bidang pariwisata (Fitriani, 2017).

Oleh karena itu, penulis akan mengevaluasi faktor-faktor penentu Generasi Z di Indonesia dalam membentuk kepercayaan kemampuan menentukan destinasi wisata Indonesia, khususnya wilayah Jabodetabek. Hal ini disebabkan karena masih sedikit atau belum ada penelitian yang mengkaji variabel social electronic word-of-mouth (e-WOM) dan travel motivation, serta efikasi keputusan perjalanan Generasi Z.

Penelitian ini bertujuan untuk (1) Untuk mengetahui hubungan yang signifikan antara social electronic word-of-mouth dan pengaruh media sosial pada efikasi keputusan perjalanan Generasi Z dalam memilih suatu destinasi wisata di Jabodetabek, dan (2) Untuk mengetahui hubungan yang signifikan 
antara travel motivation dan pengaruh media sosial pada efikasi keputusan perjalanan Generasi Z dalam memilih suatu destinasi wisata di Jabodetabek.

\section{Electronic word-of-mouth (e-WOM)}

Media sosial menjadi teknologi atau aplikasi dalam mengembangkan dan memelihara situs jejaring sosial, dengan cara posting informasi multimedia (seperti teks, gambar, audio, video), layanan berbasis teknologi, serta permainan (Albarran, 2013, hal. 2). Selain itu, ada pendapat lain berdasarkan UCL Press, bahwa saat ini media sosial merupakan tempat untuk bersosialisasi bagi semua orang, bukan hanya sebuah alat komunikasi. Tempat bersosialisasi melalui online mengenai suatu produk atau jasa sering kali disebut sebagai Electronic word-of-mouth (e-WOM). E-WOM merupakan sumber informasi penting ketika customer berbelanja produk maupun layanan di internet (Yan, Q., Wu, S., Zhou, Y., dan Zhang, L., 2018). Cheung dan Thadani (2012) menemukan sebanyak 91\% pengguna berkata bahwa berkenan untuk memberikan ulasan online, blogs, dan bentuk lain dari User-generated Content (UGC) sebelum melakukan pembelian suatu produk atau layanan, sementara $46 \%$ pengguna berkata bahwa konten ini mempengaruhi efikasi keputusan perjalanan. Dengan pesat, ulasan online terdiri dari berbagai macam wujud dan bentuk. Reviews dapat disediakan secara lokal (pada individual produk, website, atau platform), didistribusikan (pada halaman Facebook perusahaan), atau layanan perbandingan (platform yang secara eksklusif menyajikan penilaian konsumen secara keseluruhan atas barang dan jasa, seperti TripAdvisor atau Yelp) (Pettersen, 2017).

\section{Generasi $Z$}

Generasi Z merupakan generasi yang lahir pada tahun 1993 hingga 2005 (Koulopoulos \& Keldsen, 2014). Generasi ini terlahir di saat kondisi ekonomi yang tidak pasti yang membuat banyak orang menjual rumah dan aset lainnya (Monster Worldwide, 2016). Generasi ini juga dikenal sebagai digitally naif dan hyper connected junkies. Generasi $\mathrm{Z}$ menjadi generasi pertama yang mengakses teknologi komunikasi dan informasi digital dalam bentuk handphone, wifi, dan interaksi di komputer game. Generasi Z tidak pernah membayangkan dunia jika dunia tanpa internet. Generasi Z meluangkan waktu mereka rata-rata 6,5 jam setiap harinya di depan alat-alat elektronik (handphone, tv, laptop, dll). Mereka juga menulis dan mendapat balasan text sebanyak 109,5 text dalam satu hari. Dan mereka memilih smartphone sebagai benda yang terpenting dalam hidup mereka.

Meskipun Generasi Z banyak menghabiskan waktu mereka di depan alat-alat elektronik, mereka tidak selalu anti sosial. Jika dibandingkan dengan Generasi Y yang lebih sering berkomunikasi menggunakan teks, Generasi Z lebih maju dengan memanfaatkan teknologi yang memungkinkan untuk melakukan social interchange, seperti skype, facetime, bahkan melalui video game. Generasi Z lebih menyukai face to face interaction terutama melalui alat-alat komunikasi masa kini.

\section{Motivasi Perjalanan (Travel Motivation)}

Motivasi adalah keinginan atau willingness seseorang untuk sesuatu. Menurut Reeve (2015), motivasi merupakan proses internal yang dijadikan dorongan atau kebutuhan yang menginginkan perubahan, baik dalam diri maupun untuk lingkungan. Motivasi menjadikan orang terdorong dan terarah untuk keterlibatannya dengan lingkungan dengan cara yang adaptif, terbuka, dan pemecahan masalah. Motivasi merupakan faktor penting bagi wisatawan di Indonesia memutuskan apa yang harus dikunjungi. Calon wisatawan akan terlibat kemungkinan tujuan, di mana ini persepsi dihasilkan oleh preferensi individu, pengalaman sebelumnya, dan informasi diperoleh.

Beberapa faktor dalam berwisata, wisatawan memilih untuk mendapatkan pengalaman yang baru sehingga memiliki kecenderungan untuk traveling mencari pengalaman yang menyenangkan. Selain itu, 
berorientasi terhadap bucket list dan suka mencari lokasi melalui jalur yang terpencil/biasa dilalui oleh penduduk lokal (Expedia, 2017). Pengalaman merupakan hal yang umum yang dikalangan demografi wisatawan, khususnya generasi milenial. Namun untuk pengalaman yang dimaksud bukan hanya sekedar pengalaman. Adventure merupakan motivasi utama untuk traveling dengan 30\% mengatakan bahwa adventure merupakan hal yang wajib dilakukan.

\section{Efikasi Keputusan Perjalanan}

Menurut George R. Terry (2006), pengambilan keputusan merupakan salah satu pemilihan alternatif tertentu dari dua atau lebih alternatif yang ada. Sementara James A. F. Stoner berkata bahwa pengambilan keputusan adalah proses dalam memilih suatu tindakan untuk menyelesaikan permasalahan. Untuk mempermudah pengambilan keputusan menggunakan pemikiran multikriteria.

Menurut Kotler dan Keller (2012), pengambilan keputusan berkunjung berdasarkan atas pemilihan produk, pemilihan suatu brand, pemilihan saluran pembelian dan kunjungan, pemilihan waktu kunjungan, serta jumlah kunjungan. Sebelum datang ke suatu destinasi wisata, mayoritas orang terutama Generasi Z menentukan kemana akan pergi ke suatu destinasi wisata dengan mengambil keputusan sendiri maupun bersama orang lain seperti dengan teman atau keluarga. Faktor-faktor yang diutamakan oleh Generasi Z dalam memilih destinasi wisata yang akan didatangi adalah karena mereka mencari informasi melalui media sosial.

\section{Social Electronic Word-of-Mouth (e-WOM)}

Generasi Z percaya bahwa mereka paham mengenai teknologi karena mereka tidak pernah mengenal dunia tanpa smartphone dan media sosial (Zorn, 2017). Generasi Z adalah sebuah tantangan, karena perilaku mereka yang berbeda dibandingkan generasi sebelumnya yang menyebabkan perubahan perilaku konsumen. Generasi $\mathrm{Z}$ memiliki harapan tinggi, tidak setia pada brand dan lebih peduli dengan pengalaman (Schlossberg. 2016). Dengan demikian, Generasi Z sudah cakap dengan media sosial yang dapat mengambil keputusan dan memberikan pendapat mereka melalui electronic word-of-mouth (eWOM), baik secara positif maupun negatif (Qurniawati, Rina Sari dan Nurohman, Yulfan Arif, 2018).

Internet sendiri dapat menciptakan paradigma baru dalam komunikasi word of mouth dan menjadi awal munculnya istilah dari electronic word-of-mouth (e-WOM)(Qurniawati, Rina Sari dan Nurohman, Yulfan Arif, 2018). Pertumbuhan dan popularitas media sosial telah memperluas opsi konsumen untuk mengetahui informasi produk, menawarkan rekomendasi terkait konsumsi konsumen sendiri dengan terlibat dalam eWOM. Ulasan online dapat membuat pengambilan keputusan lebih mudah bagi konsumen dengan mengurangi beban kognitif (Kudeshia, C. dan Umar, A., 2017) mengingat kepopularitasan sosial eWOM telah menjadi brand communication strategies sehingga dampak pada pengambilan keputusan konsumen tidak dapat diabaikan.

Zhu dan Lai (2009) mempelajari bagaimana informasi online mempengaruhi pilihan destinasi pariwisata. Mereka menemukan bahwa volume ulasan online dan blog turis berkorelasi secara signifikan dengan populasi penerimaan wisatawan yang sebenarnya. Berdasarkan penjelasan diatas, maka hipotesis yang terbentuk adalah:

\section{H1: Terdapat hubungan yang signifikan antara social electronic word-of-mouth dan efikasi keputusan perjalanan Generasi Z.}

\section{Travel Motivation}

Travel motivation merupakan kekuatan yang berasal dari dalam diri seseorang yang mendorong dan membangkitkan minat seseorang dalam memilih tujuan tertentu dengan tujuan mendapatkan manfaat dan kepuasan yang diinginkan (Pyo et al., 1989; Yoon and Uysal, 2005). Motivasi juga dapat 
diartikan sebagai faktor socio psychological yang mendorong seseorang ke destinasi baru dan melakukan beberapa aktivitas di dalamnya (Iso Ahola, 1982).

Beard dan Ragheb (1983) mengembangkan variabel motivasi leisure berdasarkan cara kerja sistem Maslow (1970). Teori motivasi leisure terdiri dari empat motif travel, yang menentukan kepuasan pengunjung saat ikut serta dalam kegiatan rekreasi. Faktor travel yang diidentifikasi adalah: "Intelektual", yang mencakup seperti belajar dan mengeksplorasi; "Sosial". mencakup keinginan untuk mengembangkan persahabatan dan penghargaan orang lain; "Competence mastery", mencakup hal mengenai kesehatan dan kebugaran, serta; "Stimulus avoidance" yang meliputi keinginan seseorang untuk beristirahat atau bersantai dari rutinitas kegiatan sehari-hari. Penelitian ini menggunakan teori Beard dan Ragheb untuk tujuan menilai motivasi wisatawan saat melakukan travel. Teori Beard dan Ragheb untuk tujuan menilai motivasi wisatawan saat melakukan travel. Teori Beard dan Ragheb dipilih karena sejak didirikan pada tahun 1983, banyak peneliti (Mohsin et al., 2017; Albayrak dan Caber, 2018; Jia et al, 2018) telah menggunakan dan mengesahkannya.

Beberapa peneliti telah melakukan review terhadap motivasi traveling memiliki hubungan terhadap faktor-faktor demografis. Temuan penelitian ini mengungkapkan bahwa wisatawan termotivasi untuk melakukan perjalanan ke taman nasional karena kebutuhan akan alam, kegiatan, pelarian, atraksi, fotografi, keluarga, dan sosialisasi. Lebih lanjut ditunjukkan bahwa faktor sosiodemografi dan motivasi mempengaruhi keputusan pengeluaran pengunjung. Berdasarkan penjelasan di atas, maka hipotesis yang terbentuk adalah:

\section{H2: Terdapat hubungan yang signifikan antara travel motivation dengan efikasi keputusan perjalanan Generasi Z.}

\section{B. METODE PENELITIAN}

Jenis penelitian ini adalah penelitian kuantitatif untuk memenuhi tujuan penelitian yang ditentukan. Penelitian kuantitatif ini bertujuan untuk mencari keterkaitan antara setiap variabel yang nantinya dapat dijadikan sebuah kesimpulan. Dalam penelitian ini, penulis menggunakan subjek penelitian yaitu generasi Z yang berusia 17 hingga 27 tahun yang tersebar di wilayah Jabodetabek. Adapun objek penelitian pada penelitian ini adalah untuk mengetahui dan menganalisis pengaruh media sosial terhadap efikasi keputusan perjalanan Generasi $Z$ dalam memilih destinasi wisata di wilayah Jabodetabek.

Instrumen penelitian yang digunakan adalah online kuesioner yang dibagi menjadi dua bagian utama. Bagian pertama membahas secara umum informasi tentang responden. Informasi demografis seperti usia, jenis kelamin, pekerjaan, jenis sosial media yang sering digunakan, waktu penggunaan sosial media dalam sehari, dan lain-lain. Bagian ini terdiri dari delapan pertanyaan. Bagian kedua terdiri informasi yang berkaitan dengan electronic word-of-mouth dan travel motivation. Responden diminta untuk membuat peringkat daftar pernyataan electronic word-of-mouth dan travel motivation sesuai dengan tingkat kepentingannya, menunjukkan apakah pernyataan tersebut menggambarkan apa yang mereka alami saat melakukan traveling pada skala Likert dari 1 (Sangat tidak setuju) sampai 5 (Sangat setuju). Adapun variabel dalam kuesioner serta sumber jurnalnya yaitu ditampilkan pada tabel 1 .

Metode pengumpulan data yang digunakan dalam penelitian ini adalah studi literatur dan menyebarkan online kuesioner. Adapun studi literatur dilakukan melalui pencarian data melalui jurnal, majalah, artikel, beserta tesis yang terkait dengan penggunaan media sosial, sifat dan perilaku Generasi Z, serta destinasi wisata yang terdapat di Jabodetabek. Kemudian penyebaran online kuesioner ini akan dilakukan melalui aplikasi Line, WhatsApp, Instagram (story dan direct message) serta Twitter dengan kriteria responden adalah memiliki rentang usia dari 17 hingga 27 tahun, berdomisili di wilayah Jabodetabek, dan pernah melakukan traveling di wilayah Jabodetabek. 
Tabel 1. Variabel dan Sumber Jurnal Rujukan

\begin{tabular}{|l|l|}
\hline \multicolumn{1}{|c|}{ Variable } & \multicolumn{1}{c|}{ Sumber Jurnal Rujukan } \\
\hline $\begin{array}{l}\text { Social electronic word of } \\
\text { mouth }\end{array}$ & $\begin{array}{l}\text { Zorn, R. L. (2017); Schlossberg, M. (2016); Rina Sari } \\
\text { Qurniawati1, Yulfan Arif Nurohman. (2018); Kudeshia, C., \& } \\
\text { Kumar, A. (2017); Cheung, C. M. K., and D. R. Thadani } \\
\text { (2012); Zhu, M. dan Lai, S. (2009). }\end{array}$ \\
\hline Travel motivation & $\begin{array}{l}\text { Pyo et al., 1989; Yoon and Uysal, 2005; Yoo, Yoon, and } \\
\text { Eerang. (2018); Cavagnaro and Staffieri. (2015); Briliana } \\
\text { (2019); Kara and Mkwizu. (2020) }\end{array}$ \\
\hline
\end{tabular}

Dalam melakukan analisis data, peneliti menggunakan tools SPSS yang mencakup uji Validitas Pearson, uji Uji Reliabilitas Cronbach Alpha, uji Normalitas Kolmogorov-Smirnov, uji Korelasi Pearson, uji multikolinearitas, uji Autokorelasi Durbin-Watson, dan uji T-test. Dalam menguji validitas data, penulis menggunakan Uji Validitas Pearson yang dasar pengambilan keputusan dalam pengujian ini adalah jika nilai $r$ hitung lebih besar dari nilai $r$ tabel dan nilai signifikansi (Sig.) lebih kecil dari 0.05 , maka item atau data tersebut dinyatakan valid serta hasil nilai $r$ juga harus positif. Dalam menguji reliabilitas, penulis menggunakan Uji Reliabilitas Cronbach's Alpha. Dasar pengambilan keputusan dalam uji reliabilitas Cronbach's Alpha adalah jika nilai Cronbach Alpha lebih besar dari 0.6, maka kuesioner atau angket tersebut dinyatakan reliable atau konsisten. Dalam menguji normalitas, penulis menggunakan Uji Normalitas Kolmogorov-Smirnov yang bertujuan untuk mengetahui apakah nilai residual berdistribusi normal atau tidak. Model yang baik adalah jika data memiliki nilai yang berdistribusi normal. Pada pengujian korelasi, penulis menggunakan Uji Korelasi Pearson untuk mengetahui tingkat keeratan hubungan antar variabel yang dinyatakan dengan koefisien korelasi (r). Dasar pengambilan keputusannya adalah jika nilai signifikansi (Sig.) lebih kecil dari 0.05, maka terdapat korelasi antar variabel. Penulis juga menguji ada tidaknya multikolinearitas dalam data. Pengujian ini bertujuan untuk menguji apakah dalam model regresi ditemukan adanya korelasi antar variabel bebas atau tidak. Model regresi yang baik seharusnya tidak terjadi korelasi di antara variabel bebasnya. Dasar pengambilan keputusan dalam uji multikolinearitas adalah berdasarkan nilai Tolerance dan nilai VIF. Apabila nilai Tolerance lebih besar dari 0.10, dan nilai VIF lebih kecil dari 10.00 maka dinyatakan tidak terjadi multikolinieritas. Dalam menguji autokorelasi, penulis menggunakan Uji Autokorelasi Durbin-Watson yang dasar pengambilan keputusan dalam uji ini, jika nilai Durbin-Watson berada diantara nilai dU dan (4-dU), maka tidak terdapat autokorelasi. Penulis juga melakukan uji T yang dasar pengambilan keputusan dalam uji t ini adalah jika nilai signifikansi (Sig.) lebih kecil dari 0.05, maka hipotesis diterima. Hipotesis diterima mengartikan bahwa variabel independen berpengaruh signifikan terhadap variabel dependen. 


\section{HASIL DAN ANALISIS}

\section{Demografis Responden}

Usia

Tabel 2. Usia

\begin{tabular}{|c|c|c|c|c|c|}
\hline \multicolumn{6}{|c|}{ Usia } \\
\hline \multirow{13}{*}{ Valid } & & Frequency & Percent & Valid Percent & $\begin{array}{c}\text { Cumulative } \\
\text { Percent }\end{array}$ \\
\hline & 17 & 6 & 1.8 & 1.8 & 1.8 \\
\hline & 18 & 21 & 6.4 & 6.4 & 8.2 \\
\hline & 19 & 118 & 35.9 & 35.9 & 44.1 \\
\hline & 20 & 106 & 32.2 & 32.2 & 76.1 \\
\hline & 21 & 29 & 8.8 & 8.8 & 85.1 \\
\hline & 22 & 13 & 4.0 & 4.0 & 89.1 \\
\hline & 23 & 8 & 2.4 & 2.4 & 91.5 \\
\hline & 24 & 9 & 2.7 & 2.7 & 94.2 \\
\hline & 25 & 7 & 2.1 & 2.1 & 96.4 \\
\hline & 26 & 7 & 2.1 & 2.1 & 98.5 \\
\hline & 27 & 5 & 1.5 & 1.5 & 100.0 \\
\hline & Total & 329 & 100.0 & 100.0 & \\
\hline
\end{tabular}

Sumber: IBM SPSS Statistics

Berdasarkan data yang penulis kumpulkan, ada 118 responden yang merupakan tren usia pertama terbanyak, yaitu usia 19 tahun yang merepresentasikan 35.9\%. Tren kedua terbanyak adalah responden dengan usia 20 tahun yang merepresentasikan 32.2\%, dengan jumlah 106 orang. Tren ketiga terbanyak adalah responden dengan usia 21 tahun, sebanyak 29 orang, yang merepresentasikan 8.8\%. Tren usia selanjutnya diikuti dengan urutan usia 18 tahun, 22 tahun, 24 tahun, 23 tahun, 25 dan 26 tahun, 17 tahun, serta 27 tahun. 


\section{Domisili/Tempat Tinggal}

Tabel 3 Domisili Tempat Tinggal

\begin{tabular}{|c|c|c|c|c|c|}
\hline \multicolumn{6}{|c|}{ Domisili Tempat Tinggal } \\
\hline \multirow{7}{*}{ Valid } & & Frequency & Percent & Valid Percent & $\begin{array}{c}\text { Cumulative } \\
\text { Percent }\end{array}$ \\
\hline & Bekasi & 34 & 10.3 & 10.3 & 10.3 \\
\hline & Bogor & 68 & 20.7 & 20.7 & 31 \\
\hline & Depok & 24 & 7.3 & 7.3 & 38.3 \\
\hline & Tangerang & 138 & 41.9 & 41.9 & 80.2 \\
\hline & Jakarta & 65 & 19.8 & 19.8 & 100 \\
\hline & Total & 329 & 100.0 & 100.0 & \\
\hline
\end{tabular}

Sumber: IBM SPSS Statistics

Berdasarkan total responden sebanyak 329, didapatkan data bahwa domisili responden paling banyak berasal dari Jakarta yaitu sebesar $41.9 \%$ dan domisili responden paling sedikit berasal dari Depok yaitu sebesar 7.3\%.

\section{Lama penggunaan media sosial per hari}

Tabel 4. Lama Penggunaan Media Sosial Per Hari

\begin{tabular}{|c|c|c|c|c|c|}
\hline \multicolumn{7}{|c|}{ Lama Penggunaan Media Sosial Per Hari } \\
\hline \multirow{7}{*}{} & & Frequency & Percent & Valid Percent & $\begin{array}{c}\text { Cumulative } \\
\text { Percent }\end{array}$ \\
\cline { 2 - 7 } & $<2$ jam & 14 & 4.3 & 4.3 & 4.3 \\
\cline { 2 - 7 } Valid & $>6$ jam & 101 & 30.7 & 30.7 & 35.0 \\
\cline { 2 - 7 } & $2-4$ jam & 75 & 22.8 & 22.8 & 57.8 \\
\cline { 2 - 7 } & $4-6$ jam & 139 & 42.2 & 42.2 & 100.0 \\
\cline { 2 - 7 } & Total & 329 & 100.0 & 100.0 & \\
\hline
\end{tabular}

Sumber: IBM SPSS Statistics 
Dari tabel 4, dapat dikatakan bahwa sebesar $42.2 \%$ responden menghabiskan waktu menggunakan sosial media setiap harinya yaitu sebanyak 4-6 jam, dan sebesar 4.3\% responden menggunakan sosial media sebanyak $<2$ jam per hari.

\section{Validity Test}

\section{Social Electronic Word of Mouth}

Tabel 5 Validity Test Social Electronic Word of Mouth

\begin{tabular}{|c|c|c|c|c|c|c|c|c|c|c|c|c|}
\hline \multicolumn{13}{|c|}{ Correlation } \\
\hline & & $\begin{array}{l}\text { Social E- } \\
\text { WOM } 1\end{array}$ & $\begin{array}{c}\text { Social } \\
\text { E-WOM } \\
2\end{array}$ & $\begin{array}{c}\text { Social } \\
\text { E- } \\
\text { WOM } 3\end{array}$ & $\begin{array}{c}\text { Social } \\
\text { E- } \\
\text { WOM } 4\end{array}$ & $\begin{array}{c}\text { Social } \\
\text { E- } \\
\text { WOM } 5\end{array}$ & $\begin{array}{c}\text { Social } \\
\text { E- } \\
\text { WOM } 6\end{array}$ & $\begin{array}{c}\text { Social } \\
\text { E- } \\
\text { WOM } 7\end{array}$ & $\begin{array}{c}\text { Social } \\
\text { E- } \\
\text { WOM } 8\end{array}$ & $\begin{array}{l}\text { Social E- } \\
\text { WOM } 9\end{array}$ & $\begin{array}{c}\text { Social E- } \\
\text { WOM } \\
10\end{array}$ & $\begin{array}{c}\text { Sum } \\
\text { Social } \\
\text { E-WOM }\end{array}$ \\
\hline \multirow{3}{*}{$\begin{array}{l}\text { Social E- } \\
\text { WOM } 1\end{array}$} & $\begin{array}{c}\text { Pearson } \\
\text { Correlation }\end{array}$ & 1 & .107 & .507 & .453 & .374 & .222 & .314 & .286 & -.274 & .217 & .621 \\
\hline & Sig. (2-tailed) & & .052 & .000 & .000 & .000 & .000 & .000 & .000 & .000 & .000 & .000 \\
\hline & $\mathrm{N}$ & 329 & 329 & 329 & 329 & 329 & 329 & 329 & 329 & 329 & 329 & 329 \\
\hline \multirow{3}{*}{$\begin{array}{l}\text { Social E- } \\
\text { WOM } 2\end{array}$} & $\begin{array}{l}\text { Pearson } \\
\text { Correlation }\end{array}$ & .107 & 1 & .101 & .259 & .095 & .274 & .211 & .217 & -.066 & .069 & .454 \\
\hline & Sig. (2-tailed) & .052 & & .067 & .000 & .086 & .000 & .000 & .000 & .2360 & .2120 & .000 \\
\hline & $\mathrm{N}$ & 329 & 329 & 329 & 329 & 329 & 329 & 329 & 329 & 329 & 329 & 329 \\
\hline \multirow{3}{*}{$\begin{array}{l}\text { Social E- } \\
\text { WOM } 3\end{array}$} & $\begin{array}{l}\text { Pearson } \\
\text { Correlation }\end{array}$ & .507 & .101 & 1 & .513 & .273 & .262 & .199 & .224 & -.260 & .173 & .566 \\
\hline & Sig. (2-tailed) & .000 & .067 & & .000 & .000 & .000 & .000 & .000 & .000 & .002 & .000 \\
\hline & $\mathrm{N}$ & 329 & 329 & 329 & 329 & 329 & 329 & 329 & 329 & 329 & 329 & 329 \\
\hline \multirow{3}{*}{$\begin{array}{l}\text { Social E- } \\
\text { WOM } 4\end{array}$} & $\begin{array}{l}\text { Pearson } \\
\text { Correlation }\end{array}$ & .453 & .259 & .513 & 1 & .249 & .337 & .362 & .416 & -.404 & .251 & .624 \\
\hline & Sig. (2-tailed) & .000 & .000 & .000 & & .000 & .000 & .000 & .000 & .000 & .000 & .000 \\
\hline & $\mathrm{N}$ & 329 & 329 & 329 & 329 & 329 & 329 & 329 & 329 & 329 & 329 & 329 \\
\hline \multirow{3}{*}{$\begin{array}{l}\text { Social E- } \\
\text { WOM } 5\end{array}$} & $\begin{array}{l}\text { Pearson } \\
\text { Correlation }\end{array}$ & .374 & .095 & .273 & .249 & 1 & .493 & .331 & .169 & -.119 & .293 & .654 \\
\hline & Sig. (2-tailed) & .000 & .086 & .000 & .000 & & .000 & .000 & .002 & .031 & .000 & .000 \\
\hline & $\mathrm{N}$ & 329 & 329 & 329 & 329 & 329 & 329 & 329 & 329 & 329 & 329 & 329 \\
\hline \multirow{3}{*}{$\begin{array}{l}\text { Social E- } \\
\text { WOM } 6\end{array}$} & $\begin{array}{l}\text { Pearson } \\
\text { Correlation }\end{array}$ & .222 & .274 & .262 & .337 & .493 & 1 & .406 & .322 & -.254 & .197 & .628 \\
\hline & Sig. (2-tailed) & .000 & .000 & .000 & .000 & .000 & & .000 & .000 & .000 & .000 & .000 \\
\hline & $\mathrm{N}$ & 329 & 329 & 329 & 329 & 329 & 329 & 329 & 329 & 329 & 329 & 329 \\
\hline
\end{tabular}




\begin{tabular}{|c|c|c|c|c|c|c|c|c|c|c|c|c|}
\hline \multirow{3}{*}{$\begin{array}{l}\text { Social E- } \\
\text { WOM } 7\end{array}$} & $\begin{array}{l}\text { Pearson } \\
\text { Correlation }\end{array}$ & .314 & .211 & .199 & .362 & .331 & .406 & 1 & .386 & -.304 & .165 & .575 \\
\hline & Sig. (2-tailed) & .000 & .000 & .000 & .000 & .000 & .000 & & .000 & .000 & .003 & .000 \\
\hline & $\mathrm{N}$ & 329 & 329 & 329 & 329 & 329 & 329 & 329 & 329 & 329 & 329 & 329 \\
\hline \multirow{3}{*}{$\begin{array}{l}\text { Social E- } \\
\text { WOM1 }\end{array}$} & $\begin{array}{c}\text { Pearson } \\
\text { Correlation }\end{array}$ & .286 & .217 & .224 & .416 & .169 & .322 & .386 & 1 & -.468 & .082 & .451 \\
\hline & Sig. (2-tailed) & .000 & .000 & .000 & .000 & .002 & .000 & .000 & .000 & .000 & .139 & .000 \\
\hline & $\mathrm{N}$ & 329 & 329 & 329 & 329 & 329 & 329 & 329 & 329 & 329 & 329 & 329 \\
\hline \multirow{3}{*}{$\begin{array}{l}\text { Social E- } \\
\text { WOM1 }\end{array}$} & $\begin{array}{c}\text { Pearson } \\
\text { Correlation }\end{array}$ & -.274 & -.066 & -.260 & -.404 & -.119 & -.254 & -.304 & -.468 & 1 & .038 & .094 \\
\hline & Sig. (2-tailed) & .000 & 236.000 & 0.000 & 0.000 & 0.031 & 0 & 0.000 & 0.000 & & 498.000 & 0.089 \\
\hline & $\mathrm{N}$ & 329 & 329 & 329 & 329 & 329 & 329 & 329 & 329 & 329 & 329 & 329 \\
\hline \multirow{3}{*}{$\begin{array}{l}\text { Social E- } \\
\text { WOM } 10\end{array}$} & $\begin{array}{l}\text { Pearson } \\
\text { Correlation }\end{array}$ & .217 & .069 & .173 & .251 & .293 & .197 & .165 & .082 & .038 & 1 & .514 \\
\hline & Sig. (2-tailed) & .000 & .212 & .002 & .000 & .000 & .000 & .003 & .139 & .498 & & .000 \\
\hline & $\mathrm{N}$ & 329 & 329 & 329 & 329 & 329 & 329 & 329 & 329 & 329 & 329 & 329 \\
\hline \multirow{3}{*}{$\begin{array}{l}\text { Sum } \\
\text { Social E- } \\
\text { WOM }\end{array}$} & $\begin{array}{c}\text { Pearson } \\
\text { Correlation }\end{array}$ & .621 & .454 & .566 & .624 & .654 & .628 & .575 & .451 & -.094 & .514 & 1 \\
\hline & Sig. (2-tailed) & .000 & .000 & .000 & .000 & .000 & .000 & .000 & .000 & 0.089 & .000 & \\
\hline & $\mathrm{N}$ & 329 & 329 & 329 & 329 & 329 & 329 & 329 & 329 & 329 & 329 & 329 \\
\hline
\end{tabular}

Sumber: IBM SPSS Statistics

Berdasarkan hasil analisis data menggunakan Pearson, dapat diketahui bahwa WOM 9 tidak valid, karena nilai $r$ hitung lebih kecil dari nilai r tabel, dan nilai signifikansi (Sig.) lebih besar dari 0.05. Selain itu, hasil nilai r negatif, sehingga tidak valid. Namun, item lainnya dapat dinyatakan valid, karena nilai $r$ hitung (positif) lebih besar dari nilai r tabel, dan nilai signifikansi (Sig.) lebih kecil dari 0.05 .

\section{Travel Motivation}

Tabel 6 Validity Test Travel Motivation

\begin{tabular}{|c|c|c|c|c|c|c|c|c|c|c|}
\hline \multicolumn{11}{|c|}{ Correlation } \\
\hline & & $\begin{array}{c}\text { Travel } \\
\text { Motivatio } \\
\text { n } 1\end{array}$ & $\begin{array}{c}\text { Travel } \\
\text { Motivatio } \\
\text { n } 2\end{array}$ & $\begin{array}{c}\text { Travel } \\
\text { Motivatio } \\
\text { n 3 }\end{array}$ & $\begin{array}{c}\text { Travel } \\
\text { Motivatio } \\
\mathrm{n} 4\end{array}$ & $\begin{array}{c}\text { Travel } \\
\text { Motivatio } \\
\text { n } 5\end{array}$ & $\begin{array}{c}\text { Travel } \\
\text { Motivatio } \\
\text { n } 6\end{array}$ & $\begin{array}{c}\text { Travel } \\
\text { Motivatio } \\
\text { n } 7\end{array}$ & $\begin{array}{c}\text { Travel } \\
\text { Motivatio } \\
\text { n } 8\end{array}$ & \\
\hline $\begin{array}{c}\text { Travel } \\
\text { Motivation }\end{array}$ & $\begin{array}{c}\text { Pearson } \\
\text { Correlation }\end{array}$ & 1 & .380 & .434 & .293 & .207 & .325 & .277 & .237 & .655 \\
\hline
\end{tabular}


Pengaruh Media Sosial terhadap Efikasi Keputusan Perjalanan Generasi Z dalam Memilih Destinasi Wisata di Jabodetabek Sisilia Alvionita, Eveline Gaby Sutanto, Natasha Dyah Ayuningtyas, Nyoman Krisna Wati, Made Handijaya Dewantara

\begin{tabular}{|c|c|c|c|c|c|c|c|c|c|c|}
\hline \multirow[t]{2}{*}{1} & Sig. (2-tailed) & & .000 & .000 & .000 & .000 & .000 & .000 & .000 & .000 \\
\hline & $\mathrm{N}$ & 329 & 329 & 329 & 329 & 329 & 329 & 329 & 329 & 329 \\
\hline \multirow{3}{*}{$\begin{array}{c}\text { Travel } \\
\text { Motivation } \\
2\end{array}$} & $\begin{array}{l}\text { Pearson } \\
\text { Correlation }\end{array}$ & .380 & 1 & .378 & .323 & .223 & .182 & .245 & .291 & .651 \\
\hline & Sig. (2-tailed) & .000 & & .000 & .000 & .000 & .001 & .000 & .000 & .000 \\
\hline & $\mathrm{N}$ & 329 & 329 & 329 & 329 & 329 & 329 & 329 & 329 & 329 \\
\hline \multirow{3}{*}{$\begin{array}{c}\text { Travel } \\
\text { Motivation } \\
3\end{array}$} & $\begin{array}{l}\text { Pearson } \\
\text { Correlation }\end{array}$ & .434 & .378 & 1 & .302 & .221 & .351 & .185 & .206 & .652 \\
\hline & Sig. (2-tailed) & .000 & .000 & & .000 & .000 & .000 & .001 & .000 & .000 \\
\hline & $\mathrm{N}$ & 329 & 329 & 329 & 329 & 329 & 329 & 329 & 329 & 329 \\
\hline \multirow{3}{*}{$\begin{array}{c}\text { Travel } \\
\text { Motivation } \\
4\end{array}$} & $\begin{array}{l}\text { Pearson } \\
\text { Correlation }\end{array}$ & .293 & .323 & .302 & 1 & .047 & .217 & .203 & .113 & .541 \\
\hline & Sig. (2-tailed) & .000 & .000 & .000 & & .398 & .000 & .000 & .040 & .000 \\
\hline & $\mathrm{N}$ & 329 & 329 & 329 & 329 & 329 & 329 & 329 & 329 & 329 \\
\hline \multirow{3}{*}{$\begin{array}{c}\text { Travel } \\
\text { Motivation } \\
5\end{array}$} & $\begin{array}{l}\text { Pearson } \\
\text { Correlation }\end{array}$ & .207 & .223 & .221 & .047 & 1 & .151 & .200 & .137 & .505 \\
\hline & Sig. (2-tailed) & .000 & .000 & .000 & .000 & & .006 & .000 & .013 & .000 \\
\hline & $\mathrm{N}$ & 329 & 329 & 329 & 329 & 329 & 329 & 329 & 329 & 329 \\
\hline \multirow{3}{*}{$\begin{array}{c}\text { Travel } \\
\text { Motivation } \\
6\end{array}$} & $\begin{array}{l}\text { Pearson } \\
\text { Correlation }\end{array}$ & .325 & .182 & .351 & .217 & .151 & 1 & .149 & .103 & .523 \\
\hline & Sig. (2-tailed) & .000 & .001 & .000 & .000 & .006 & & .007 & .061 & .000 \\
\hline & $\mathrm{N}$ & 329 & 329 & 329 & 329 & 329 & 329 & 329 & 329 & 329 \\
\hline \multirow{3}{*}{$\begin{array}{c}\text { Travel } \\
\text { Motivation } \\
7\end{array}$} & $\begin{array}{l}\text { Pearson } \\
\text { Correlation }\end{array}$ & .277 & .245 & .185 & .203 & .200 & .149 & 1 & .336 & .571 \\
\hline & Sig. (2-tailed) & .000 & .000 & .001 & .000 & .000 & .007 & & .000 & .000 \\
\hline & $\mathrm{N}$ & 329 & 329 & 329 & 329 & 329 & 329 & 329 & 329 & 329 \\
\hline \multirow{3}{*}{$\begin{array}{c}\text { Travel } \\
\text { Motivation } \\
8\end{array}$} & $\begin{array}{l}\text { Pearson } \\
\text { Correlation }\end{array}$ & .237 & .291 & .206 & .113 & .137 & .103 & 336 & 1 & .530 \\
\hline & Sig. (2-tailed) & .000 & .000 & .000 & .040 & .013 & .061 & .000 & & .000 \\
\hline & $\mathrm{N}$ & 329 & 329 & 329 & 329 & 329 & 329 & 329 & 329 & 329 \\
\hline \multirow{3}{*}{$\begin{array}{c}\text { Sum Travel } \\
\text { Motivation }\end{array}$} & $\begin{array}{l}\text { Pearson } \\
\text { Correlation }\end{array}$ & .655 & .651 & .652 & .541 & .505 & .523 & .571 & .530 & 1 \\
\hline & Sig. (2-tailed) & .000 & .000 & .000 & .000 & .000 & .000 & .000 & .000 & \\
\hline & $\mathrm{N}$ & 329 & 329 & 329 & 329 & 329 & 329 & 329 & 329 & 329 \\
\hline
\end{tabular}

Sumber: IBM SPSS Statistics 
Berdasarkan hasil analisis data, dapat diketahui data ini valid, karena seluruh item 'Travel Motivation' memiliki nilai $r$ hitung lebih besar dibandingkan $r$ tabel, dan nilai signifikansi (Sig.) juga lebih kecil dari 0.05 .

\section{Efikasi Keputusan Perjalanan Generasi Z}

Tabel 7 Validity Test Efikasi Keputusan Perjalanan Generasi Z

\begin{tabular}{|c|c|c|c|c|c|c|c|c|c|c|c|c|}
\hline \multicolumn{13}{|c|}{ Correlations } \\
\hline & & $\begin{array}{l}\text { Efikas } \\
\text { i } \\
\text { Keput } \\
\text { usan } \\
\text { Perjal } \\
\text { anan } \\
\text { Gener } \\
\text { asi Z 1 }\end{array}$ & $\begin{array}{l}\text { Efikas } \\
\text { i } \\
\text { Keput } \\
\text { usan } \\
\text { Perjal } \\
\text { anan } \\
\text { Gener } \\
\text { asi Z 2 }\end{array}$ & $\begin{array}{l}\text { Efikas } \\
\text { i } \\
\text { Keput } \\
\text { usan } \\
\text { Perjal } \\
\text { anan } \\
\text { Gener } \\
\text { asi Z 3 }\end{array}$ & $\begin{array}{l}\text { Efikas } \\
\text { i } \\
\text { Keput } \\
\text { usan } \\
\text { Perjal } \\
\text { anan } \\
\text { Gener } \\
\text { asi Z 4 }\end{array}$ & $\begin{array}{l}\text { Efikas } \\
\text { i } \\
\text { Keput } \\
\text { usan } \\
\text { Perjal } \\
\text { anan } \\
\text { Gener } \\
\text { asi Z } 5\end{array}$ & $\begin{array}{l}\text { Efikas } \\
\text { i } \\
\text { Keput } \\
\text { usan } \\
\text { Perjal } \\
\text { anan } \\
\text { Gener } \\
\text { asi Z 6 }\end{array}$ & $\begin{array}{l}\text { Efikas } \\
\text { i } \\
\text { Keput } \\
\text { usan } \\
\text { Perjal } \\
\text { anan } \\
\text { Gener } \\
\text { asi Z 7 }\end{array}$ & $\begin{array}{l}\text { Efikas } \\
\text { i } \\
\text { Keput } \\
\text { usan } \\
\text { Perjal } \\
\text { anan } \\
\text { Gener } \\
\text { asi Z 8 }\end{array}$ & $\begin{array}{l}\text { Efikas } \\
\text { i } \\
\text { Keput } \\
\text { usan } \\
\text { Perjal } \\
\text { anan } \\
\text { Gener } \\
\text { asi Z 9 }\end{array}$ & $\begin{array}{l}\text { Efikas } \\
\text { i } \\
\text { Keput } \\
\text { usan } \\
\text { Perjal } \\
\text { anan } \\
\text { Gener } \\
\text { asi Z } \\
10\end{array}$ & $\begin{array}{l}\text { Sum } \\
\text { Efikas } \\
\text { i } \\
\text { Keput } \\
\text { usan } \\
\text { Perjal } \\
\text { anan } \\
\text { Gener } \\
\text { asi Z }\end{array}$ \\
\hline \multirow{3}{*}{$\begin{array}{l}\text { Efikasi } \\
\text { Keputu- } \\
\text { san } \\
\text { Perjala- } \\
\text { nan } \\
\text { Generasi } \\
\text { Z } 1\end{array}$} & $\begin{array}{l}\text { Pears } \\
\text { on } \\
\text { Correl } \\
\text { ation }\end{array}$ & 1 & .596 & .498 & .394 & .299 & .357 & .193 & .210 & .398 & .115 & .587 \\
\hline & $\begin{array}{l}\text { Sig. } \\
(2- \\
\text { tailed) }\end{array}$ & & .000 & .000 & .000 & .000 & .000 & .000 & .000 & .000 & .037 & .000 \\
\hline & $\mathrm{N}$ & 329 & 329 & 329 & 329 & 329 & 329 & 329 & 329 & 329 & 329 & 329 \\
\hline \multirow{3}{*}{$\begin{array}{l}\text { Efikasi } \\
\text { Keputusa } \\
\mathrm{n} \\
\text { Perjalana } \\
\mathrm{n} \\
\text { Generasi } \\
\text { Z } 2\end{array}$} & $\begin{array}{l}\text { Pears } \\
\text { on } \\
\text { Correl } \\
\text { ation }\end{array}$ & .596 & 1 & .471 & .434 & .366 & .333 & .195 & .213 & .430 & .132 & .606 \\
\hline & $\begin{array}{l}\text { Sig. } \\
(2- \\
\text { tailed })\end{array}$ & .000 & & .000 & .000 & .000 & .000 & .000 & .000 & .037 & .017 & .000 \\
\hline & $\mathrm{N}$ & 329 & 329 & 329 & 329 & 329 & 329 & 329 & 329 & 329 & 329 & 329 \\
\hline \multirow{3}{*}{$\begin{array}{l}\text { Efikasi } \\
\text { Keputusa } \\
\text { n } \\
\text { Perjalana } \\
\text { n } \\
\text { Generasi } \\
\text { Z } 3\end{array}$} & $\begin{array}{l}\text { Pears } \\
\text { on } \\
\text { Correl } \\
\text { ation }\end{array}$ & .498 & .471 & 1 & .368 & .319 & .308 & .180 & .245 & .343 & .062 & .558 \\
\hline & $\begin{array}{l}\text { Sig. } \\
(2- \\
\text { tailed) }\end{array}$ & .000 & .000 & .000 & .000 & .000 & .000 & .001 & .000 & .000 & .259 & .000 \\
\hline & $\mathrm{N}$ & 329 & 329 & 329 & 329 & 329 & 329 & 329 & 329 & 329 & 329 & 329 \\
\hline \multirow{2}{*}{$\begin{array}{l}\text { Efikasi } \\
\text { Keputusa } \\
\text { n } \\
\text { Perjalana } \\
\text { n } \\
\text { Generasi } \\
\text { Z } 4\end{array}$} & $\begin{array}{l}\text { Pears } \\
\text { on } \\
\text { Correl } \\
\text { ation }\end{array}$ & .394 & .434 & .368 & 1 & .661 & .373 & .317 & .403 & .361 & .204 & .698 \\
\hline & $\begin{array}{l}\text { Sig. } \\
\text { (2- }\end{array}$ & .000 & .000 & .000 & & .000 & .000 & .000 & .000 & .000 & .000 & .000 \\
\hline
\end{tabular}




\begin{tabular}{|c|c|c|c|c|c|c|c|c|c|c|c|c|}
\hline & tailed) & & & & & & & & & & & \\
\hline & $\mathrm{N}$ & 329 & 329 & 329 & 329 & 329 & 329 & 329 & 329 & 329 & 329 & 329 \\
\hline \multirow{3}{*}{$\begin{array}{l}\text { Efikasi } \\
\text { Keputusa } \\
\text { n } \\
\text { Perjalana } \\
\text { n } \\
\text { Generasi } \\
\text { Z } 5\end{array}$} & $\begin{array}{l}\text { Pears } \\
\text { on } \\
\text { Correl } \\
\text { ation }\end{array}$ & .299 & .366 & .319 & .661 & 1 & .442 & .406 & .444 & .349 & .213 & .705 \\
\hline & $\begin{array}{l}\text { Sig. } \\
(2- \\
\text { tailed) }\end{array}$ & .000 & .000 & .000 & .000 & & .000 & .000 & .000 & .000 & .000 & .000 \\
\hline & $\mathrm{N}$ & 329 & 329 & 329 & 329 & 329 & 329 & 329 & 329 & 329 & 329 & 329 \\
\hline \multirow{3}{*}{$\begin{array}{l}\text { Efikasi } \\
\text { Keputusa } \\
\text { n } \\
\text { Perjalana } \\
\text { n } \\
\text { Generasi } \\
\text { Z } 6\end{array}$} & $\begin{array}{l}\text { Pears } \\
\text { on } \\
\text { Correl } \\
\text { ation }\end{array}$ & .357 & .333 & .308 & .373 & .442 & 1 & .541 & .557 & .308 & .362 & .753 \\
\hline & $\begin{array}{l}\text { Sig. } \\
(2- \\
\text { tailed })\end{array}$ & .000 & .000 & .000 & .000 & .000 & & .000 & .000 & .000 & .000 & .000 \\
\hline & $\mathrm{N}$ & 329 & 329 & 329 & 329 & 329 & 329 & 329 & 329 & 329 & 329 & 329 \\
\hline \multirow{3}{*}{$\begin{array}{l}\text { Efikasi } \\
\text { Keputusa } \\
\text { n } \\
\text { Perjalana } \\
\text { n } \\
\text { Generasi } \\
\text { Z } 7\end{array}$} & $\begin{array}{l}\text { Pears } \\
\text { on } \\
\text { Correl } \\
\text { ation }\end{array}$ & .193 & .195 & .180 & .317 & .406 & .541 & 1 & .704 & .220 & .209 & .677 \\
\hline & $\begin{array}{l}\text { Sig. } \\
(2- \\
\text { tailed) }\end{array}$ & .000 & .000 & .001 & .000 & .000 & .000 & & .000 & .000 & .000 & .000 \\
\hline & $\mathrm{N}$ & 329 & 329 & 329 & 329 & 329 & 329 & 329 & 329 & 329 & 329 & 329 \\
\hline \multirow{3}{*}{$\begin{array}{l}\text { Efikasi } \\
\text { Keputusa } \\
\text { n } \\
\text { Perjalana } \\
\text { n } \\
\text { Generasi } \\
\text { Z } 8\end{array}$} & $\begin{array}{l}\text { Pears } \\
\text { on } \\
\text { Correl } \\
\text { ation }\end{array}$ & .210 & .213 & .245 & ..403 & .444 & .577 & .704 & 1 & .245 & .226 & .677 \\
\hline & $\begin{array}{l}\text { Sig. } \\
(2- \\
\text { tailed) }\end{array}$ & .000 & .000 & .000 & .000 & .000 & .000 & .000 & & .000 & .000 & .000 \\
\hline & $\mathrm{N}$ & 329 & 329 & 329 & 329 & 329 & 329 & 329 & 329 & 329 & 329 & 329 \\
\hline \multirow{3}{*}{$\begin{array}{l}\text { Efikasi } \\
\text { Keputusa } \\
\text { n } \\
\text { Perjalana } \\
\text { n } \\
\text { Generasi } \\
\text { Z } 9\end{array}$} & $\begin{array}{l}\text { Pears } \\
\text { on } \\
\text { Correl } \\
\text { ation }\end{array}$ & .390 & .430 & .343 & .361 & .349 & .308 & .220 & .245 & 1 & .123 & .559 \\
\hline & $\begin{array}{l}\text { Sig. } \\
(2- \\
\text { tailed })\end{array}$ & .000 & .000 & .000 & .000 & .000 & .000 & .000 & .000 & & .000 & .000 \\
\hline & $\mathrm{N}$ & 329 & 329 & 329 & 329 & 329 & 329 & 329 & 329 & 329 & 329 & 329 \\
\hline
\end{tabular}




\begin{tabular}{|c|c|c|c|c|c|c|c|c|c|c|c|c|}
\hline \multirow{3}{*}{$\begin{array}{l}\text { Efikasi } \\
\text { Keputusa } \\
\text { n } \\
\text { Perjalana } \\
\text { n } \\
\text { Generasi } \\
\text { Z } 10\end{array}$} & $\begin{array}{l}\text { Pears } \\
\text { on } \\
\text { Correl } \\
\text { ation }\end{array}$ & .115 & .132 & .062 & .204 & .213 & .362 & .209 & .226 & .123 & 1 & .456 \\
\hline & $\begin{array}{l}\text { Sig. } \\
\text { (2- } \\
\text { tailed) }\end{array}$ & .037 & .017 & .259 & .000 & .000 & .000 & .000 & .000 & .026 & & .000 \\
\hline & $\mathrm{N}$ & 329 & 329 & 329 & 329 & 329 & 329 & 329 & 329 & 329 & 329 & 329 \\
\hline \multirow{3}{*}{$\begin{array}{l}\text { Sum } \\
\text { Efikasi } \\
\text { Keputusa } \\
\text { n } \\
\text { Perjalana } \\
\text { n } \\
\text { Generasi } \\
\text { Z }\end{array}$} & $\begin{array}{l}\text { Pears } \\
\text { on } \\
\text { Correl } \\
\text { ation }\end{array}$ & .587 & .606 & .558 & 698 & .705 & .753 & .677 & .716 & .559 & .546 & 1 \\
\hline & $\begin{array}{l}\text { Sig. } \\
\text { (2- } \\
\text { tailed) }\end{array}$ & .000 & .000 & .000 & .000 & .000 & .000 & .000 & .000 & .000 & .000 & \\
\hline & $\mathrm{N}$ & 329 & 329 & 329 & 329 & 329 & 329 & 329 & 329 & 329 & 329 & 329 \\
\hline
\end{tabular}

Sumber: IBM SPSS Statistics

Berdasarkan hasil analisis data, dapat diketahui bahwa data ini valid, karena seluruh item 'Efikasi Keputusan Perjalanan Generasi Z' memiliki nilai r hitung lebih besar daripada r tabel, dan nilai signifikansi (Sig.) juga lebih kecil dari 0.05

\section{Reliability Test}

\section{Social Electronic Word of Mouth}

Tabel 8 Reliability Test Social Electronic Word-of-Mouth

\section{Reliability Statistics}

\begin{tabular}{|c|c|}
\hline Cronbach's Alpha & N of items \\
\hline .765 & 9 \\
\hline
\end{tabular}

Sumber: IBM SPSS Statistics

Setelah melakukan uji validitas, diketahui bahwa item WOM 9 tidak valid, sehingga penulis tidak menggunakannya saat menguji reliabilitas. Berdasarkan hasil analisis di atas, dapat diketahui bahwa seluruh item tersebut reliable, karena nilai Cronbach's Alpha lebih besar dari 0.6, yaitu dengan nilai keseluruhan sebesar 0.765 .

\section{Travel Motivation}

Tabel 9 Reliability Test Travel Motivation

\begin{tabular}{|c|c|}
\multicolumn{2}{c}{ Reliability Statistics } \\
\hline Cronbach's Alpha & N of items \\
\hline .707 & 8 \\
\hline
\end{tabular}

Sumber: IBM SPSS Statistics 
Berdasarkan hasil analisa di atas, dapat diketahui bahwa seluruh item tersebut reliable, karena nilai Cronbach's Alpha lebih besar dari 0.6, yaitu dengan nilai keseluruhan sebesar 0.707.

\section{Efikasi Keputusan Perjalanan Generasi Z}

Tabel 10 Reliability Test Efikasi Keputusan Perjalanan Generasi Z

\section{Reliability Statistics}

\begin{tabular}{|c|c|}
\hline Cronbach's Alpha & N of items \\
\hline .827 & 10 \\
\hline
\end{tabular}

Sumber: IBM SPSS Statistics

Berdasarkan hasil analisa di atas, dapat diketahui bahwa seluruh item tersebut reliable, karena nilai Cronbach's Alpha lebih besar dari 0.6, yaitu dengan nilai Cronbach's Alpha keseluruhan sebesar 0.827.

\section{Normality Test}

Tabel 11 Normality Test

One-Sample Kolmogorov-Smirnov Test

\begin{tabular}{|l|l|l|}
\hline & & Unstandardized Residual \\
\hline N & & 329 \\
\hline Normal Parameters & Mean & .0000000 \\
\hline $\begin{array}{l}\text { Most Extreme } \\
\text { Differences }\end{array}$ & Std. Deviation & 4.93057587 \\
\hline \multicolumn{2}{|l|}{ Absolute } & 0.044 \\
\hline Test Statistics & & \\
\hline Assymp. Sig. (2-tailed) & & 0.029 \\
\hline a. Test distribution is Normal. & -.044 \\
\hline b. Calculated from data. & .044 \\
\hline c. Lilliefors Significance Correction. \\
\hline d. This is a lower bound of the true significance. \\
\hline
\end{tabular}

Sumber: IBM SPSS Statistics

Uji normalitas dengan Kolmogorov-Smirnov pada tabel diatas, menunjukkan bahwa nilai signifikansi bernilai 0.200 , di mana 0.200 lebih besar dari 0.05 , maka data atau hasil kuesioner ini dapat dikatakan distribusi normal (normal). 


\section{Hypothesis Testing}

\section{Hipotesis 1}

H1: Terdapat hubungan yang signifikan antara social electronic word-of-mouth dan Efikasi Keputusan Perjalanan Generasi Z.

Tabel 12 ANOVA Test Hypothesis 1

\begin{tabular}{|l|l|c|c|c|c|c|}
\hline Model & & Sum of Squares & df & Mean Square & F & Sig. \\
\hline 1 & Regression & 2683.287 & 1 & 2683.287 & 95.877 & .000 \\
\hline & Residual & 9151.692 & 327 & 27.987 & & \\
\hline & Total & 11834.979 & 328 & & & \\
\hline a. Dependent Variable: Sum Efikasi Keputusan Perjalanan Generasi Z \\
\hline \multicolumn{7}{|l|}{ b. Predictors: (Constant), Sum Social E-WOM } \\
\hline
\end{tabular}

\section{Sumber: IBM SPSS Statistics}

Dari tabel diatas, diketahui bahwa nilai F hitung sebesar 95.877, dikarenakan nilai F hitung 95.877 $>$ nilai F tabel 2.996, maka dapat disimpulkan bahwa hipotesis diterima atau dengan kata lain variabel 'Social Electronic Word-of-Mouth' berpengaruh terhadap variabel 'Efikasi Keputusan Perjalanan Generasi Z'.

Tabel 13 Nilai Signifikansi Hypothesis 1

\section{Correlations}

\begin{tabular}{|c|c|c|c|}
\hline & & $\begin{array}{c}\text { Sum Efikasi Keputusan } \\
\text { Perjalanan Generasi Z }\end{array}$ & $\begin{array}{l}\text { Sum Travel } \\
\text { Motivation }\end{array}$ \\
\hline \multirow[t]{2}{*}{$\begin{array}{l}\text { Pearson } \\
\text { Correlation }\end{array}$} & $\begin{array}{l}\text { Sum Efikasi Keputusan } \\
\text { Perjalanan Generasi Z }\end{array}$ & 1.000 & .476 \\
\hline & Sum Travel Motivation & .476 & 1.000 \\
\hline \multirow[t]{2}{*}{ Sig. (1-tailed) } & $\begin{array}{l}\text { Sum Efikasi Keputusan } \\
\text { Perjalanan Generasi Z }\end{array}$ & . & .000 \\
\hline & Sum Travel Motivation & .000 & . \\
\hline \multirow[t]{2}{*}{$\mathrm{N}$} & $\begin{array}{l}\text { Sum Efikasi Keputusan } \\
\text { Perjalanan Generasi Z }\end{array}$ & 329 & 329 \\
\hline & Sum Travel Motivation & 329 & 329 \\
\hline
\end{tabular}

Sumber: IBM SPSS Statistics

Pada tabel diatas, nilai signifikansi untuk variabel Social Electronic Word of Mouth dan Efikasi Keputusan Perjalanan Generasi Z adalah $0.000<0.05$, sehingga kedua variabel 
memiliki hubungan atau berkorelasi.

Variabel Social Electronic Word of Mouth terhadap Efikasi Keputusan Perjalanan Generasi Z memiliki pearson correlation sebesar 0.476 , sehingga memiliki bentuk hubungan positif dengan derajat korelasi sedang. Semakin tinggi Social Electronic Word-of-Mouth maka semakin tinggi efikasi keputusan perjalanan generasi Z atau semakin rendah Social Electronic Word-of-Mouth maka semakin rendah efikasi keputusan perjalanan generasi Z.

Tabel 14. Model Summary Hypothesis 1

\begin{tabular}{|c|c|c|c|c|c|}
\hline Model & $\mathrm{R}$ & R Square & $\begin{array}{c}\text { Adjusted } \\
\text { R Square }\end{array}$ & $\begin{array}{c}\text { Std. Error of } \\
\text { the Estimate }\end{array}$ & $\begin{array}{c}\text { Durbin- } \\
\text { Watson }\end{array}$ \\
\hline 1 & .476 & .227 & .224 & 5.290 & 1.790 \\
\hline \multicolumn{6}{|c|}{ a. Predictors: (Constant), Sum Social E-WOM } \\
\hline \multicolumn{6}{|c|}{ b. Dependent Variable: Sum Efikasi Keputusan Perjalanan Generasi Z } \\
\hline
\end{tabular}

Sumber: IBM SPSS Statistics

Berdasarkan tabel 'Model Summary', dapat diketahui bahwa pengaruh yang diberikan variabel independen terhadap variabel dependen sebesar 22.7\%. Sedangkan, berdasarkan nilai Durbin-Watson, dapat diketahui bahwa data ini terdapat autokorelasi, karena nilai Durbin-Watson data ini lebih kecil dari nilai dU [1.7990], yaitu 1.790.

Tabel 15 Model Regresi Hypothesis 1

\begin{tabular}{|c|l|c|c|c|c|c|c|c|}
\hline & & \multicolumn{2}{c|}{$\begin{array}{c}\text { Unstandardized } \\
\text { Coefficients }\end{array}$} & $\begin{array}{c}\text { Standardized } \\
\text { Coefficients }\end{array}$ & & & \multicolumn{2}{c|}{ Collinearity Statistics } \\
\hline Model & & B & Std. Error & Beta & $\mathrm{t}$ & Sig. & Tolerance & VIF \\
\hline 1 & (Constant) & 13.341 & 2.613 & & 5.106 & .000 & & \\
\hline & $\begin{array}{l}\text { Sum Social } \\
\text { E-WOM }\end{array}$ & .664 & .068 & .476 & 9.792 & .000 & 1.000 & 1.000 \\
\hline \\
a. Dependent Variable: Sum Efikasi Keputusan Perjalanan Generasi Z & & \\
\hline
\end{tabular}

Sumber: IBM SPSS Statistics

Dalam model regresi, nilai tolerance pada variabel Electronic Word of Mouth adalah 1.00. Maka dari itu, data ini dapat dikatakan tidak terjadi multikolinearitas, karena nilainya lebih besar dibandingkan 0.10 , yaitu $1.00>0.10$.

Sama halnya dengan nilai tolerance, nilai VIF model regresi pada variabel Electronic Word-of-Mouth juga memiliki nilai sebesar 1.00, maka dapat dinyatakan bahwa data ini tidak terjadi multikolinearitas, karena bernilai $1.00<10.00$. 
Selain itu, dengan uji t, kesimpulan yang dapat ditarik adalah sebagai berikut. Hipotesis pertama mempunyai nilai signifikansi sebesar 0.000. Artinya, hipotesis ini diterima, dan adanya hubungan signifikan antara Social Electronic Word-of-Mouth dan efikasi keputusan perjalanan generasi Z.

\section{Hipotesis 2}

H2: Terdapat hubungan yang signifikan antara travel motivation dan Efikasi Keputusan Perjalanan Generasi Z.

Tabel 16 ANOVA Test Hypothesis 2

ANOVA

\begin{tabular}{|l|l|c|c|c|c|c|}
\hline Model & & Sum of Squares & df & Mean Square & F & Sig. \\
\hline 1 & Regression & 2687.668 & 1 & 2687.668 & 96.079 & .000 \\
\hline & Residual & 9147.310 & 327 & 27.973 & & \\
\hline & Total & 11834.979 & 328 & & & \\
\hline c. Dependent Variable: Sum Efikasi Keputusan Perjalanan Generasi Z & \\
\hline & d. Predictors: (Constant), Sum Travel Motivation \\
\hline
\end{tabular}

Sumber: IBM SPSS Statistics

Dari tabel diatas, diketahui bahwa nilai F hitung sebesar 96.079, dikarenakan nilai F hitung 96.079 > nilai F tabel 2.996, maka dapat disimpulkan bahwa variabel 'Travel Motivation' berpengaruh terhadap variabel 'Efikasi Keputusan Perjalanan Generasi Z' atau dengan kata lain hipotesis tersebut diterima.

Tabel 17 Nilai Signifikansi Hypothesis 2

\begin{tabular}{|c|c|c|c|}
\hline \multicolumn{4}{|c|}{ Correlations } \\
\hline & & $\begin{array}{c}\text { Sum Efikasi Keputusan } \\
\text { Perjalanan Generasi Z }\end{array}$ & $\begin{array}{l}\text { Sum Travel } \\
\text { Motivation }\end{array}$ \\
\hline \multirow[t]{2}{*}{$\begin{array}{l}\text { Pearson } \\
\text { Correlation }\end{array}$} & $\begin{array}{l}\text { Sum Efikasi Keputusan } \\
\text { Perjalanan Generasi Z }\end{array}$ & 1.000 & .477 \\
\hline & Sum Travel Motivation & .477 & 1.000 \\
\hline \multirow[t]{2}{*}{ Sig. (1-tailed) } & $\begin{array}{l}\text { Sum Efikasi Keputusan } \\
\text { Perjalanan Generasi Z }\end{array}$ & . & .000 \\
\hline & Sum Travel Motivation & .000 & . \\
\hline \multirow[t]{2}{*}{$\mathrm{N}$} & $\begin{array}{l}\text { Sum Efikasi Keputusan } \\
\text { Perjalanan Generasi Z }\end{array}$ & 329 & 329 \\
\hline & Sum Travel Motivation & 329 & 329 \\
\hline
\end{tabular}

Sumber: IBM SPSS Statistics 
Variabel Travel Motivation terhadap Efikasi Keputusan Perjalanan Generasi Z memiliki pearson correlation sebesar 0.477 , sehingga memiliki bentuk hubungan positif dengan derajat korelasi sedang. Semakin tinggi Travel Motivation maka akan semakin tinggi efikasi keputusan perjalanan generasi Z, atau semakin rendah Travel Motivation maka akan semakin rendah pula efikasi keputusan perjalanan generasi $\mathrm{Z}$.

Tabel 18 Model Summary Hypothesis 2

\begin{tabular}{|c|c|c|c|c|c|}
\hline Model & $\mathrm{R}$ & R Square & $\begin{array}{l}\text { Adjusted } \\
\text { R Square }\end{array}$ & $\begin{array}{c}\text { Std. Error of } \\
\text { the Estimate }\end{array}$ & $\begin{array}{c}\text { Durbin- } \\
\text { Watson }\end{array}$ \\
\hline 1 & .477 & .227 & .225 & 5.289 & 1.854 \\
\hline \multicolumn{6}{|c|}{ c. Predictors: (Constant), Sum Travel Motivation } \\
\hline \multicolumn{7}{|c|}{ d. Dependent Variable: Sum Efikasi Keputusan Perjalanan Generasi Z } \\
\hline
\end{tabular}

Sumber: IBM SPSS Statistics

Berdasarkan tabel 'Model Summary', variabel independen memberikan pengaruh secara parsial maupun simultan sebesar $22.7 \%$ terhadap variabel dependen. Sedangkan, berdasarkan nilai DurbinWatson, dapat diketahui bahwa data ini tidak terdapat autokorelasi, karena nilainya terletak diantara dU [1.7990] dan (4-dU) [2.201], yaitu 1.854.

Tabel 19 Model Regresi Hypothesis 2

\begin{tabular}{|c|c|c|c|c|c|c|c|c|}
\hline \multicolumn{9}{|c|}{ Coefficients } \\
\hline & & \multicolumn{2}{|c|}{$\begin{array}{l}\text { Unstandardized } \\
\text { Coefficients }\end{array}$} & \multirow{2}{*}{$\begin{array}{c}\begin{array}{c}\text { Standardized } \\
\text { Coefficients }\end{array} \\
\text { Beta }\end{array}$} & \multirow[b]{2}{*}{$\mathrm{t}$} & \multirow[b]{2}{*}{ Sig. } & \multicolumn{2}{|c|}{ Collinearity Statistics } \\
\hline Model & & B & Std. Error & & & & Tolerance & VIF \\
\hline 1 & (Constant) & 16.130 & 2.328 & & 6.929 & 0.000 & & \\
\hline & \begin{tabular}{|l} 
Sum \\
Travel \\
Motivation
\end{tabular} & .687 & .070 & .477 & 9.802 & 0.000 & 1.000 & 1.000 \\
\hline
\end{tabular}

\section{Sumber: IBM SPSS Statistics}

Berdasarkan tabel 'Coefficients', data ini memiliki nilai Tolerance dan nilai VIF sebesar 1.000, maka kesimpulannya adalah data ini tidak ada gejala multikolinearitas.

Selain itu, melalui uji t, kesimpulan yang dapat ditarik adalah sebagai berikut. Hipotesis kedua menunjukkan bahwa hubungan antara Travel Motivation dan efikasi keputusan perjalanan generasi Z mempunyai nilai signifikansi sebesar 0.000. Artinya, hipotesis diterima. 

berikut.

Dari kedua hasil uji hipotesis, penulis mendapatkan 'theoretical framework' penelitian sebagai

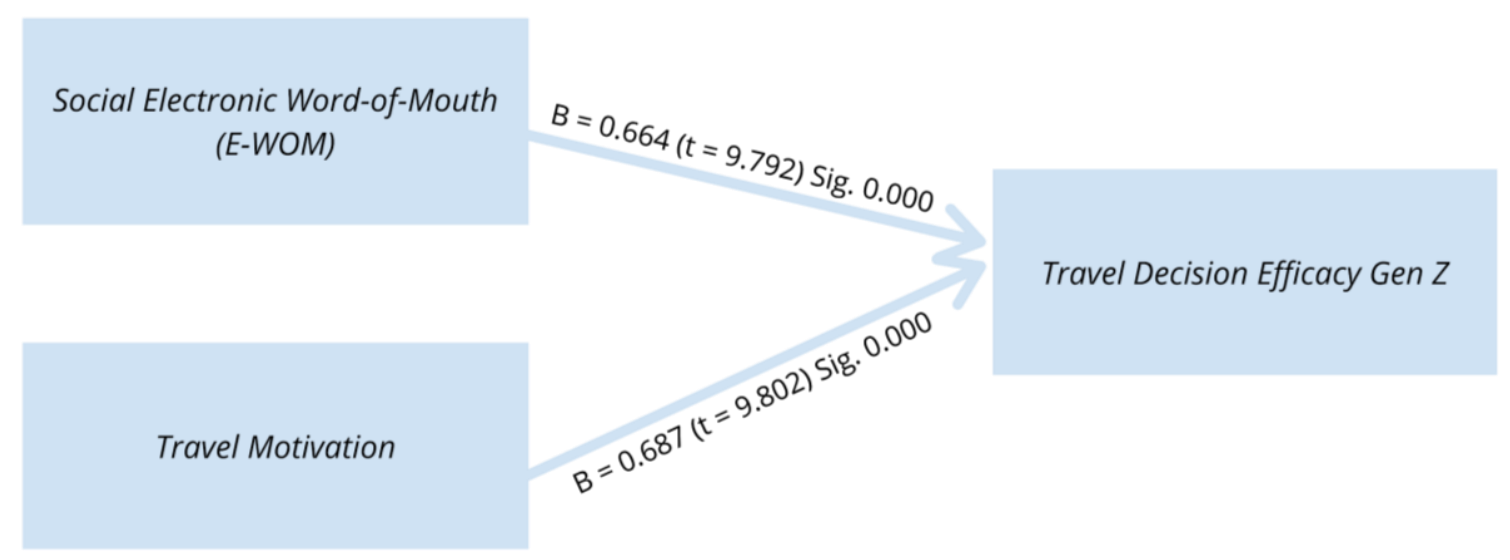

\section{Uji Regresi Berganda (Multiple Regression)}

Tabel 1.19 Multiple Regression Test

Ringkasan Analisis Regresi Berganda (Multiple Regression)

\begin{tabular}{l|c|c|c|}
\hline Variabel & Koefisien Regresi & t hitung & Sig. \\
\hline Konstanta & 4.216 & & \\
\hline Sum Social E-WOM & 0.477 & 6.926 & 0.000 \\
\hline Sum Travel Motivation & 0.494 & 6.939 & 0.000 \\
\hline F hitung = & 78.928 \\
R Square = & 0.326
\end{tabular}

Berdasarkan tabel di atas, nilai signifikansi (Sig.) dalam uji F menunjukkan bahwa variabel 'Sum Social e-WOM' dan 'Sum Travel Motivation' secara bersama-sama/simultan berpengaruh secara signifikan terhadap variabel 'Efikasi Keputusan Perjalanan Generasi Z' dengan nilai signifikansi sebesar 0.000. Selain itu, diketahui juga bahwa nilai $\mathrm{F}$ hitung bernilai 78.928, maka dapat disimpulkan bahwa hipotesis diterima dengan pernyataan F hitung $78.928>$ F tabel 2.996. Artinya, variabel 'Sum Social eWOM' dan 'Sum Travel Motivation' secara simultan berpengaruh terhadap variabel 'Efikasi Keputusan Perjalanan Generasi Z'.

Tabel output 'Model Summary Hipotesis 1' menunjukkan bahwa nilai R Square adalah 0.326 atau sebesar 32.6\%. Artinya, variabel 'Sum Social e-WOM' dan 'Sum Travel Motivation' secara simultan berpengaruh terhadap variabel 'Efikasi Keputusan Perjalanan Generasi Z' sebesar 32.6\%.

Selain itu, tabel output 'Coefficients' menunjukkan bahwa nilai thitung variabel 'Sum Social e-WOM' adalah 6.926. Maka kesimpulannya adalah hipotesis pertama diterima dengan kenyataan bahwa nilai $\mathrm{t}$ hitung 6.926 > nilai t tabel 1.960. Artinya, Social e-WOM memiliki pengaruh terhadap Efikasi Keputusan Perjalanan Generasi Z. Sedangkan, nilai t hitung variabel 'Sum Travel Motivation' adalah 6.939. Maka dapat disimpulkan bahwa hipotesis kedua juga diterima dengan nilai t hitung 6.939 > nilai t tabel 1.960. Dengan kata lain, Travel Motivation memiliki pengaruh terhadap Efikasi Keputusan Perjalanan Generasi Z. 


\section{Path Analysis}

\section{Direct Effect}

Peneliti juga melakukan analisis pengaruh Social e-WOM dan Travel Motivation terhadap Efikasi Keputusan Perjalanan Generasi Z dalam penelitian ini. Di mana Social e-WOM dan Travel Motivation berperan sebagai independent variable, sedangkan Efikasi Keputusan Perjalanan Generasi Z sebagai dependent variable. Dari hasil penyebaran kuesioner dan analisis data kuesioner melalui SPSS - khususnya uji hipotesis - didapatkan hasil sebagai berikut.

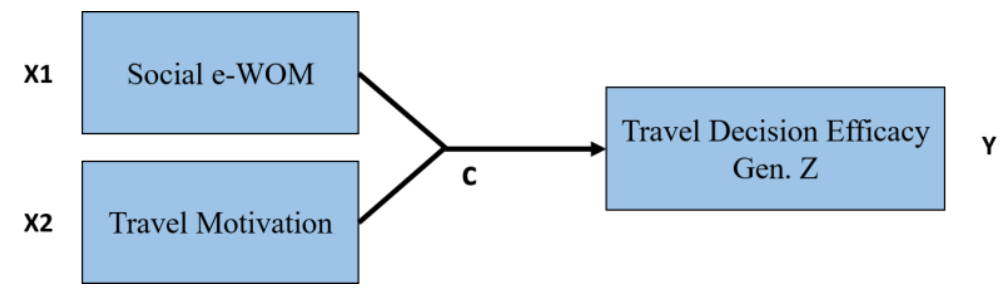

Dari hasil analisis tersebut, maka terbentuk kesimpulan bahwa variabel Social e-WOM dan Travel Motivation sama-sama memiliki nilai signifikansi sebesar 0.000. Dalam hal ini, terdapat teori bahwa hubungan antara variabel bebas dengan variabel terikat dapat diterima apabila nilai signifikansinya lebih kecil dari 0.05. Oleh karena itu, kesimpulan yang dapat ditarik, yaitu adanya hubungan atau pengaruh antara Social e-WOM dengan Efikasi Keputusan Perjalanan Generasi Z, dan variabel Travel Motivation memiliki hubungan atau pengaruh terhadap Efikasi Keputusan Perjalanan Generasi Z di Jabodetabek.

\section{SIMPULAN}

Berdasarkan penelitian di atas, perbedaan dalam social electronic word-of-mouth dan motivasi perjalanan di antara Generasi Z yang berdomisili di wilayah Jabodetabek tidak homogen. Oleh karena itu, perhitungan efikasi keputusan perjalanan mereka juga tidak dapat disamakan. Tujuan dan motivasi perjalanan Generasi Z yang berdomisili di Jakarta belum tentu sama dengan Generasi Z yang berdomisili di Bogor, Depok, Tangerang, ataupun Bekasi.

Para Generasi Z percaya bahwa online review di media sosial memberikan fakta, kemudian menggunakan online review tersebut sebagai bahan pertimbangan dalam mengambil keputusan dalam berwisata. Mereka juga sering membaca ataupun membagikan pengalaman berwisata dalam media sosial yang sering digunakan. Selain itu, motivasi berwisata seperti mengeksplorasi dunia, mempererat hubungan pertemanan dan penghargaan terhadap orang lain, meningkatkan kesehatan dan kebugaran, serta keinginan untuk memiliki waktu istirahat dan bersantai dari rutinitas sehari-hari, dapat mempengaruhi Generasi $Z$ dalam memperkuat efikasi keputusan berwisatanya, terutama dalam memilih destinasi wisata.

Peneliti berharap agar penelitian yang telah dibuat ini mampu memberikan sumbangsih untuk pendidikan serta berguna bagi para pelaku industri dalam bidang hospitality. Dengan mengetahui data/informasi terkait efikasi keputusan perjalanan generasi Z, pelaku industri harus dapat/mampu meningkatkan strategi pemasaran, khususnya dalam menyampaikan benefit atau experience apa yang akan didapatkan pengunjung saat mengunjungi destinasi wisata tersebut. Dalam hal ini, manajer destinasi di wilayah Jabodetabek juga harus dapat memperkuat citra destinasi dan menjaga ulasan pengunjung di media sosial, serta mempromosikan destinasi tersebut sebagai tujuan untuk mendapatkan pengalaman, belajar mengenai hal baru, memperbaiki kemampuan (skill) diri, serta mengembangkan kebugaran fisik. Selain itu, pelaku industri juga harus dapat/mampu menggunakan media sosial sebagai tools yang efektif 
dalam membangun awareness dan engagement pengunjung, mengingat penggunaan media sosial untuk generasi Z di Jabodetabek mencapai 4 hingga 6 jam sehari.

Penelitian ini mencatat beberapa keterbatasan yang mungkin dapat digunakan sebagai bahan pembelajaran untuk penelitian selanjutnya. Pertama, pengumpulan data ini dilaksanakan ketika masa PSBB dan periode ujian akhir semester, di mana para Generasi Z sedang fokus pada pengerjaan tugas kuliah, tugas akhir semester, serta struggle pada pekerjaan masing-masing. Oleh karena itu, ada baiknya jika pengumpulan data diambil ketika subjek penelitian (dalam penelitian ini, Generasi Z) sedang dalam masa liburan atau saat waktu kosong. Kedua, penelitian ini hanya terbatas kepada Generasi Z yang berdomisili di wilayah Jabodetabek dan pernah berwisata ke wilayah Jabodetabek. Sedangkan, berwisata ke luar pulau dan luar negeri lebih menarik bagi sebagian besar Generasi $\mathrm{Z}$ yang berdomisili di Jabodetabek. Oleh karena itu, untuk penelitian selanjutnya, sebaiknya dapat memilih subjek penelitian yang lebih relevan dan tepat. Ketiga, dalam penelitian hanya berfokus terhadap pengujian dua variabel independen yaitu Social e-WOM dan Travel Motivation terhadap Efikasi Keputusan Perjalanan Generasi Z. Sedangkan masih ada berbagai macam faktor lainnya (indirect effect) yang berperan dalam penentuan Efikasi Keputusan Perjalanan Generasi Z.

\section{Daftar Referensi}

\section{Journal Article}

Abid, N. (2017). Peluang dan Tantangan Pelayanan Perpustakaan Berbasis Media Sosial : Perspektif Pustakawan Stain Kudus, (ed 5.), pp. 47-68.

Bassiouni, D. H., \& Hackley, C. (2014). Generation Z children's adaptation to digital consumer culture: A critical literature review. Journal of Customer Behaviour, 13(2), pp 113-133. Beard, J. and Ragheb, M. (1983). Measuring leisure motivation. Journal of Leisure Research, Vol. 15, pp. 219-228.

Briliana, Vita. (2019). What do Millennials see in Indonesia? An analysis of Generation Y travel intentions through Social Media. African Journal of Hospitality, Tourism and Leisure, GCBSS Special Edition.

Cavagnaro, Elena and Staffieri, S. (2015). A Study of Students' Travellers Values and Needs in Order to Establish Futures Patterns and Insights. JOURNAL OF TOURISM FUTURES VOL. 1 NO. 2 2015, pp. 94-107, Emerald Group Publishing Limited, ISSN 2055-5911

Cheung, C. M. K., and D. R. Thadani. (2012). The impact of electronic word-of-mouth communication: A literature analysis and integrative model. Decision Support Systems 54: pp. 461-70.

Fitriani, Y. (2017). Analisis Pemanfaatan Berbagai Media Sosial sebagai Sarana Penyebaran Informasi bagi Masyarakat. Diakses dari https://ejournal.bsi.ac.id/ejurnal/index.php/paradigma/article/view/2120/1708

Fukami, N., Yamada, K., \& Uchiyama, Y. (2014). Capturing the Dynamics and Changes of Global Megacities From a Living Environment Point of View. The Report on Global City History. The Megacities Project. Research Institute for Humanity (RIHN). Diakses dari https://repository.kulib.kyotou.ac.jp/dspace/bitstream/2433/210474/1/jsd.v8n1p108.pdf

George, R. Terry. (2006). EWOM: the impact of customer-to-customer online know-how exchange on customer value and loyalty. Journal of BusinessResearch, Vol. 59 No. 4, pp. 449-56.

Iso Ahola, S. (1982). Toward a Social Psychology Theory of Tourism Motivation. Annals of Tourism Research, Vol. 12, pp. 256-262.

Kara, N.S, and Kezia Herman Mkwizu. (2020). Demographic factors and travel motivation among leisure tourists in Tanzania. International Hospitality Review Emerald Publishing Limited. 
Kudeshia, C., \& Kumar, A. (2017). Social eWOM: does it affect the brand attitude and purchase intention of brands? Management Research Review, 40(3), 310-330.

Kozak, M. (2002). Comparative analysis of tourist motivations by nationality and destinations. Tourism Management, Vol. 23 No. 3, pp. 221-232.

Mohsin, A., Lengler, J. and Chaiya, P. (2017). Does travel interest mediate between motives and intention to travel? A case of young Asian travelers. Journal of Hospitality and Tourism Management, Vol. 31, pp. 36-44.

Pettersen, L. (2017). Rating mechanisms among participants in sharing economy platforms. First Monday22. doi:10.5210/fm.v22i12.7908.

Pyo, S., B. Mihalik, and M. Uysal. (1989). Attraction Attributes and Motivations: A Canonical Correlation An\&\&. Annals of Tourism Research, 16, pp. 277-282.

Rina Sari Qurniawati1, Yulfan Arif Nurohman. (2018). eWOM Pada Generasi Z Di Social Media. Jurnal Ekonomi Manajemen Sumber Daya Vol. 20, No. 2.

Saayman, M. and Saayman, A. (2009). Why travel motivational and socio-demographics matter in managing a national park, Koedoe, Vol. 51 No. 1, pp. 1-9.

Sugiyono. 2011. Metode Penelitian Kuantitatif, Kualitatif dan R\&D. Bandung: Alfabeta Taylor, P., \& Keeter, S. (2010). Millennials: A portrait of generation next. Washington, DC: Pew Research Center. Retrieved from 6 Maret 2020, http://www.pewsocialtrends.org/les/2010/10/millennials-condent-connected-opento-chan ge.pdf.

Yan, Q., Wu, S., Zhou, Y., \& Zhang, L. (2018). How differences in eWOM platforms impact consumers' perceptions and decision-making. Journal of Organizational Computing and Electronic Commerce, 28(4), pp. 315-333.

Yoo, Chang-Keun, Donghwan Yoon and Eerang Park. Tourist motivation: an integral approach to destination choices, (2018). pp. 169-185.

Yoon, Yooshik \& Uysal, Muzaffer. (2005). An Examination of the Effects of Motivation and Satisfaction on Destination Loyalty: A Structural Model. Tourism Management. 26. 45-56. 10.1016/j.tourman.2003.08.016.

Zhu, M. and Lai, S. (2009). Paper presented at the International Conference on Electronic Commerce and Business Intelligence (ECBI), Beijing, 6-7 June, available at: http://ieeexplore.ieee.org/stamp/stamp.jsp?arnumber $1 / 405189500$. Retrieved from 8 April 2020.

Zorn, R. L. (2017). Coming in 2017: A New Generation of Graduate Students--The Z Generation. College \& University, 92(1), 61-63.

\section{Book}

Albarran, A. B. (2013). The Social Media Industries. Diakses pada 2 April 2020, dari (https://books.google.co.id/books?id=lX50qh2WRKoC\&pg=PA2\&lpg=PA2\&dq=the+tec hnologies+or+applications+that+people+use+in+developing+and+maintaining+their+s oc

ial+networking+sites. + This+involves + the + posting + of + multimedia + information $+($ e.g., $+\mathrm{t}$ e $\mathrm{xt}$,+images,+audio,+video),+location-

based+services+(e.g.,+Foursquare),+gaming+(e.g.+

Farmville,+Mafia+Wars)] \&source=bl\&ots=7RJ9BVayT5\&sig=ACfU3U2qLi_mYXq2C

9Twlej0mpXIl5Wpbw\&hl=en\&sa=X\&ved=2ahUKEwiJpfCM8MnoAhXEXisKHZGgC

PwQ6AEwAHoECAwQKA\#v=onepage\&q=the technologies or applications that people use in developing and maintaining their social networking sites. This involves the posting of multimedia information (e.g., text, images, audio, video), location-based services (e.g., Foursquare), gaming (e.g. Farmville, Mafia Wars)] \&f=false). 
Hunsinger, J., \& Senft, T. M. (2014). The Social Media Handbook. Diakses pada 2 April 2020, dari https://books.google.co.id/books?id=nXHhAQAAQBAJ\&pg=PA1\&lpg=PA1\&dq=netwo rked+information+services+designed+to+support+in-

depth+social+interaction,+community+formation,+collaborative+opportunities+and+co llaborative+work\&source=bl\&ots=B JGIBC4qs_\&sig=ACfU3U0lrN81F-Mgmfwpo1YS7r6jCA54A\&hl=en\&sa=X\&ved=2ah UKEwiVyeGW68noAhUF8HMBHRwAmoQ6AEwAHoECAsQKA\#v=onepage \&q=net worked information services designed to support in-depth social interaction, community formation, collaborative opportunities and collaborative work\&f=false.

Kuncoro, Mudrajad. 2009. Metode Riset Untuk Bisnis \& Ekonomi. Penerbit Erlangga. Jakarta. Kotler, dan Keller. (2012). Manajemen Pemasaran. Edisi 12. Jakarta: Erlangga Koulopoulos, T., \& Keldsen, D. (2014). The Six Forces Shaping the Future of Business: The Gen $Z$ Effect. New York and Oxon: Bibli-omotion Inc.

Kholil, S., (Ed), (2011). Teori Komunikasi Massa. Bandung: Cipta Pustaka Media.

\section{Internet Source}

Jumlah Penduduk Provinsi DKI Jakarta Menurut Kelompok Umur dan Jenis Kelamin, (2018). Diakses pada 3 April 2020, dari https://jakarta.bps.go.id/dynamictable/2019/09/16/58/jumlah-penduduk-provinsidki-jaka rta-menurut-kelompok-umur-dan-jenis-kelamin-2018-.html.

Okezone techno, 2020. Pengguna Media Sosial di Dunia Capai 3,8 Miliar Retrieved from https://techno.okezone.com/read/2020/02/20/207/2171425/pengguna-media-sosialdi-du nia-capai-3-8-miliar.

Reeve, J. (2015). Understanding motivation and emotion (6th ed.). Hoboken, NJ: Wiley. Retrieved from https://kumparan.com/kumparanfood/7-destinasi-kuliner-legendarisdi-pasar-lama-tange rang-1544605535174937979. Retrieved from 3 April 2020.

Schlossberg, M. (2016). Teen Generation Z is being called 'millennials on steroids,' and that could be terrifying for retailers. Retrieved from 9 Juli, 2016, Business Insider UK: http://uk.businessinsider.com/millennials-vs-gen-z-2016-2 